\title{
Religião e poder estatal no Brasil: da Colônia à República
}

Religion and state power in Brazil: from the Colony to the Republic

\author{
David Mesquiati de Oliveira* \\ Leila Miranda Damasceno** \\ Lucia Maria Roriz Verissimo Portela** \\ Robson Prati Neves de Oliveira ${ }^{* * * *}$ \\ https://doi.org/10.29327/256659.12.2-15
}

Resumo:

O objetivo do artigo é pontuar como se deu a relação entre o poder estatal e a religião nas Constituições brasileiras, desde o periodo colonial até a Constituição Federal de 1988. A relação Igreja e Estado não ocorreu uniformemente no Brasil. Ao contrário, as várias Constituições nacionais mantiveram vínculos e criaram rupturas entre uma Constituição e outra, sustentando a tensão entre os ideais separatistas e os confessionais na relação Igreja e Estado. A primeira seção trata do conceito abrangente de religião e sua relação com a sociedade, a partir de Durkheim e Eliade. A segunda, retomará o conceito de poder estatal a partir da teoria geral do Estado, de Hobbes e Rousseau. A terceira e última seção, analisará a relação entre religião e Estado brasileiro a partir das suas Constituições federais ao longo da história do Brasil.

Palavras-Chave: Religião. Estado. Direito. Laicidade.

\begin{abstract}
:
The aim of thisarticle is to point out how the relationship between State power and religion occurred in the Brazilian Constitutions, from the colonial period up to the 1988 Federal Constitution. The relationship between Church and State did not occur uniformly in Brazil. On the contrary, the various national Constitutions maintained links and created ruptures between one Constitution and another, sustaining the tension between separatist and confessional ideals in the relationship between Church and State. In the first section, the comprehensive concept of religion and its relationship with society, from Durkheim and Eliade, shall be reflected on. In the second section, the concept of State power based on the general theory of the State, by Hobbes and Rousseau, shall be taken up. In the third and final section, the relationship between religion and the Brazilian State based on its federal constitutions throughout its history shall be analyzed.
\end{abstract}

Keyword: Religion; State; Right; Secularism.

"Doutor e Mestre em Teologia, bacharel em Ciências Econômicas e em Teologia, licenciado em História. Docente do Programa de Pós-Graduação em Ciências das Religiões da Faculdade Unida de Vitória (PPGCR-UNIDA). E-mail: david@fuv.edu.br.

${ }^{* *}$ Mestranda em Ciências das Religiões no PPGCR da Faculdade Unida de Vitória, graduada em Fonoaudiologia e em Educação Física. E-mail: le.md@hotmail.com

${ }^{* * *}$ Mestranda em Ciências das Religiões no PPGCR da Faculdade Unida de Vitória, graduada em Direito. E-mail: luciaroriz@yahoo.com.br

${ }^{* * * *}$ Mestrando em Ciências das Religiões no PPGCR da Faculdade Unida de Vitória, graduado em Teologia e em Filosofia. E-mail: perobson@gmail.com 


\section{Introdução}

A religião é um fenômeno universal que se mostra na formação dos povos. A nação brasileira não seria uma exceção. Desde o Brasil colonial até a contemporaneidade, a religião desempenhou importante papel. Para evidenciar essa influência, o artigo está dividido em três momentos históricos no Brasil: colonial, imperial e republicano.

A primeira seção visa esclarecer a origem e a conceituação de religião a partir do pensamento de Durkheim (1996) e de Eliade (1992), que abordam a gênese da religião, bem como sua influência na sociedade. Durkheim a analisa como um fato social que atinge a coletividade, admitindo que a mesma é um todo integrado. Sob o olhar de Eliade, o indivíduo experimenta a realidade profana (secular), no entanto, busca incessantemente a presença do sacro, querendo permanecer no coração do sagrado.

A segunda seção apresenta o Estado e o poder estatal a partir da Teoria Geral do Estado. O fundamento teórico é a teoria da origem contratual do Estado, denominada de racionalista. Esta teoria justifica que o mesmo, tem início a partir de uma convenção (pactual, contratual), e, como produto da razão humana (pactista, contratualista).

Hobbes (2003) considera a inquietação dos indivíduos e a necessidade de se estabelecer um contrato social. Teriam abdicado de seus direitos em nome de um maior, fundando o Estado. Rousseau (1999) funda o contrato na igualdade dos seres humanos, denominada de vontade geral. Na parte relativa ao estado de natureza, a filosofia de Rousseau é oposta à de Hobbes. Para este autor, o estado de natureza primevo era um tempo de guerra mútua, enquanto, para Rousseau, era de felicidade perfeita, dado que o ser humano, em estado de natureza, é sadio, ágil e robusto. Todavia, nessa parte, a fundamentação teórica reside no entendimento de Hobbes que não é tão restrito. Com relação ao poder estatal, a teoria contratualista acentua que pactos sucessivos foram se firmando para dotá-lo de força e capacidade de proteção. Nessa perspectiva, o Estado é constituído pelos individuos, podendo recorrer à força e ao recurso de todos, convenientemente, para assegurar a paz e a defesa comum.

A terceira seção apresenta a análise da relação entre a religião e Estado, sob o enfoque do Brasil colonial e das posteriores Constituições Federais, desde o Brasil imperial à Constituição de 1988, com destaque aos vínculos, rupturas e 
dificul-dades existentes, abordando os distintos sistemas de relação entre essas grandezas, bem como os conceitos de laicidade e laicismo.

\section{Religião: origem e conceituação}

A religião é um fenômeno universal presente nas diversas culturas, existindo desde os primórdios. Dificilmente se encontrará um grupo social que não possua alguma forma de religiosidade a reger seus costumes, seu cotidiano e suas vidas (ASSIS \& KUMPEL, 2011, p. 69). A expressão religião remonta à palavra latina religio, significando, em seu primeiro sentido, um agrupamento de regras, observâncias, advertências e interdições, sem quaisquer referências a divindades, rituais, mitos ou quaisquer outras manifestações que, hodiernamente, entendemos como religiosas (SILVA, 2004, p. 2).

Segundo Sena (2016, p. 65), a expressão latina re-ligare tem referência no religar do ser humano com seus antepassados, mortos ou desencarnados, atitude codificada pela realização de rituais fúnebres e sepultamentos, constituindo a base embrionária da atitude religiosa, que sempre influenciou a relação dos indivíduos com o mundo, consigo mesmo, com os outros e com o que ele crê que está além deste mundo.

Ao analisar a religião, Durkheim (1996) a considera um fato social, já que engendra a essência da sociedade, sendo esta a alma da religião. Trata-se de "um sistema solidário de crenças e de práticas relativas a coisas sagradas, isto é, separadas, proibidas, crenças e práticas que reúnem numa mesma comunidade moral, chamada igreja, todos aqueles que a elas aderem" (DURKHEIM, 1996, p. 262). A essência da religião está contida no sagrado, como algo extraordinário. $O$ seu oposto, o profano, relaciona-se com as coisas ordinárias e mundanas. As distinções entre ambos, sagrado e profano, não coincidem com a distinção entre sobrenatural e natural. Coisas sobrenaturais não são necessariamente coisas sagradas, nem coisas sagradas são sobrenaturais. O sagrado está associado ao social. As crenças religiosas são representações coletivas e os principais rituais religiosos são praticados coletivamente (DURKHEIM, 1996, p. 32).

A investida da transformação da natureza da religião, segundo Eliade (1992), ocorre com o reconhecimento da manifestação do sagrado, isto é, das hierofanias. Para Eliade, as religiões se manifestam desde as hierofanias, somente existindo quando estas estão presentes. Elas são responsáveis pelo rompimento 
da homogeneidade do espaço profano. Quando ocorrem essas manifestações, uma realidade absoluta, um centro, um ponto fixo absoluto é revelado, e o ser humano religioso sempre investiu no sentido de se estabelecer no Centro do Mundo (ELIADE, 1992, p. 47).

Eliade alude que a hierofania é algo consagrador de um espaço, que se abre para o alto, realizando a comunicação com o céu. É a interface entre o céu e terra. A religião é resultado das hierofanias que produzem o rompimento de níveis, sendo que a existência humana carece da comunicação perene que ela estabelece com o céu. $O$ indivíduo tem a tendência de se mover unicamente num mundo santificado, fundado pelo sagrado. E é do próprio sagrado a responsabilidade de estabelecer a ordem naquele mundo, a ordem cósmica. Nesse raciocínio, o profano é ilimitado, não possuindo referências. Somente a experiência do sagrado estabelece os limites e as referências. E mais, somente ela é a própria referência (ELIADE, 1992, p. 48).

Segundo Coutinho (2012), na perspectiva eliadiana e durkheiminiana, o profano e o sagrado são realidades distintas. O ser humano, no seu início, via o sagrado como a divindade, posteriormente passou a distingui-los. Citando Borau, salienta que o sagrado é a ponte entre a divindade e o ser humano, convertendose de divindade em hierofania (COUTINHO, 2012, p. 176).

Nessa abordagem, a religião é a grande integradora da vida social. Logo, as diferenças e os conflitos entre os diferentes grupos sociais são deixados à margem em razão das afinidades existentes entre a fé, a religiosidade e os valores. Essa força integradora garante o reajustamento social e o equilíbrio de conflitos de classe, étnicos, dentre outros, favorecendo um sistema social integrado. Além disso, propicia auxílio às pessoas frente a situações econômicas debilitadas e tensões politicas (SCOTT, 2006, p. 47).

\section{Estado e poder estatal}

Nesta seção, evidencia-se o conceito de Estado, sua origem e seus elementos formadores, explicitando que a reunião de ideias e o senso comum deram origem à sociedade natural e esta, objetivando a eficácia do bem comum, através de regras e organização politica, formulou a ideia de Estado e o influxo da religião em sua formação. 
De acordo com Hobbes (2003), a doutrina teológico-religiosa de Tomás de Aquino e de Agostinho de Hipona pregava que tudo foi criado por Deus. A origem do Estado não seria proveniente do ser humano, nem do coletivo ou da ordem social, mas da Força maior que organizou o humano, transformando-o de homem-natural à homem-social (HOBBES, 2003, p. 143).

Thomas Hobbes, que viveu entre 1588 e 1679, foi integrante da teoria contratualista do Estado. Entendia que o ser humano vivera sem poder e sem organização, num período em que ele o denominou estado de natureza, o qual representava uma condição de guerra. Com intuito de evitar a guerra, Hobbes propôs que houve a necessidade de se criar o Estado para controlar e reprimir o indivíduo que vivia em estado de natureza. Logo, o Estado seria o único capaz de produzir a paz, e para tanto, o ser humano deveria ser supervisionado pelo Ente Estatal, legitimado por um contrato social (HOBBES, 2003, p. 143).

Nessa linha, o único caminho para erigir um poder comum, capaz de defender os seres humanos contra a invasão dos estrangeiros e contra as injúrias alheias, será conferir todo o poder e fortaleza a um indivíduo ou a uma assembleia de pessoas, que, por pluralidade de votos, possam reduzir suas vontades a uma vontade. Isto equivale dizer: eleger um indivíduo ou uma assembleia de pessoas que represente sua personalidade; e que cada um considere como próprio e se reconheça a si mesmo como autor de qualquer coisa que faça ou promova quem representa sua pessoa, naquelas coisas que concernem à paz e à segurança comum (HOBBES, 2003, p. 35).

John Locke refuta as ideias de Hobbes, aludindo ao estado de natureza um estado de perfeita liberdade, não sendo, todavia, um estado de licença. Era regido por uma lei natural que obrigava cada um, e, a razão, confundida com esta lei, ensinava o ser humano, sendo iguais e independentes, que nenhum deveria criar obstáculo a outro em sua vida, liberdade e em seus bens. Os indivíduos se uniram com intuito de formar uma sociedade, abdicando de uma parcela de sua liberdade natural, sem autorizar que as regras seriam impostas unilateralmente por um soberano, mas sim, por um pacto social (LOCKE, 2018).

Segundo Rousseau (1999), o Estado é convencional. Resulta da vontade geral, que é a soma da volição manifestada pela maioria dos indivíduos. A nação (povo organizado) é superior ao rei. Não há direito divino da Coroa, mas, sim, direito legal decorrente da soberania estatal. Esta é ilimitada, ilimitável, total e 
incontrastável. O Governo é instituído para promover o bem comum, e só é suportável enquanto justo. Caso não corresponda aos anseios populares que determinaram sua organização, o povo pode substituí-lo ante a autorização do direito, refazendo o contrato. Nessa vertente, o contrato social tem o objetivo de

encontrar uma forma de associação que defenda e proteja a pessoa e os bens de cada associação de qualquer força comum, e pela qual, cada um, unindo-se a todos, não obedeça, portanto, senão a si mesmo, ficando assim tão livre como dantes (ROUSSEAU, 1999, p. 35).

Maquiavel (2010), um dos precursores da ciência política e primeiro a ordenar os fundamentos do Direito Público moderno, introduz a expressão Estado na literatura científica em sua consagrada obra $O$ Príncipe, publicada em 1513. Seu objetivo, como cientista político, consistia em instaurar um Estado estável que pusesse fim ao eterno ciclo de instabilidade e caos reinante na dinâmica social de seu tempo (MAQUIAVEL, 2010, p. 11).

Para Darcy Azambuja (1997, p. 6), o Estado Moderno é uma sociedade à base territorial, dividida em governantes e governados, e que pretende, nos limites do território reconhecido, a supremacia, sobre as demais instituições. De fato, é o supremo e legal depositário da vontade social e fixa a situação de todas as organizações. Dalmo de Abreu Dallari (2007, p. 48) expõe este aspecto do Estado, quando preceitua que ele existe em função dos interesses de todos os indivíduos que o compõem, e para o atendimento desses interesses busca a consecução de fins gerais, visando atingir esses objetivos. Ele exerce um poder para alcançar eficácia, sobrepondo-se aos demais poderes e submetendo até aqueles que the dão existência.

Segundo Maluf (1998, p. 23), o Estado possui três elementos constitutivos, sendo que a falta de qualquer elemento descaracteriza a sua formação: povo, território e soberania.O povo é a reunião de individuos sujeitos às mesmas leis, os súditos, os cidadãos de um mesmo Estado, considerando-se o aspecto puramente jurídico (AZAMBUJA,1997, p. 19). Mario Lúcio Quintão Soares (2008, p. 152), citando Kriele, menciona uma distinção entre povo e nação, sendo esta, o povo que adquiriu consciência ou a consciência de pertencer à mesma comunidade.

O segundo elemento do Estado é o território, a base física, onde a soberania é exercida na sua plenitude. Esse âmbito geográfico da nação é onde ocorre a validade da sua ordem jurídica. A nação, como realidade sociológica, pode sub- 
sistir sem território próprio, sem se constituir em Estado. Todavia, Estado sem território não é Estado (DANTAS, 2008, p. 91).

O último elemento, a soberania, é a qualidade essencial do Estado, o direito ou poder de emitir comandos obrigatórios (KELSEN, 2000, p. 301). Águila (2005, p. 23), ao tratar de soberania e poder do Estado, afirma ser produto de uma relação, em que alguns obedecem e outros mandam, estando relacionado a valores que propiciam autoridade e legitimidade para mandar, e o assentimento para ser obedecida. Para Águila (2005, p. 26), rotineiramente, o poder caracteriza a autoridade, sendo esta a expressão do poder legitimado no momento em que as relações sociais entre governantes e governados se estabilizam. A obediência é uma consequência sem necessidade de se recorrer à força ou, à violência.

Dallari (2006, p. 33), com base nos estudos da teoria de Burdeau, afirma que o poder é um elemento essencial ou uma nota característica do Estado e contém certas peculiaridades que o qualificam. A mais importante é a soberania. Para Reale (2000, p. 112), não pode existir Direito Positivo sem o poder. O Direito estatal, para ter o grau de plena positividade jurídica, depende da existência do poder. Ele propicia a organização da coação através da aplicação das normas jurídicas. Direito positivo e poder, por conseguinte, são termos inseparáveis, sendo que vão procurar reduzir o primeiro ao segundo, ou, contrapor um ao outro.

\section{A relação entre Estado brasileiro e religião}

Esta seção apresenta a interconexão entre Estado e religião, como resultado da história brasileira desde o século XVI. Demonstra o poder construído, no período colonial, quando o catolicismo foi declarado religião oficial, e funcionava como instrumento de dominação social, politica e cultural. Em seguida, trata as relações de poder entre Estado e religião após a proclamação da independência em 1822 e demais Constituições brasileiras até 1988.

\section{Aspectos do Brasil colonial}

Igreja e Estado se confundiam enquanto instituições legitimadoras do poder e normatizadoras dos corpos e das mentes. Ambas as instituições tinham como pretensão a regulação dos princípios organizadores da sociedade, a conquista da consciência dos sujeitos e a detenção do monopólio do capital simbóli- 
co no imaginário social. À época, a nação brasileira foi regida pela legislação portuguesa, ou seja, pelas Ordenações (Manuelinas, Afonsinas e Filipinas), quando o direito esta-tal se confundia com o direito divino, isto é, o direito ditado pela Igreja Católica (EMMERICK, 2010, p. 145).

Segundo Martins e Câmara (2012), a religião sempre esteve presente, consequentemente, refletida, em maior ou menor grau, nas leis do país. O Brasil, desde a sua colonização contou com a forte presença da Igreja Católica, que foi a religião oficial durante parte de sua história. Esta presença é perceptivel na cultura, nos costumes e nos valores deste corpo social.

O padroado sacramentava a união entre Igreja e Estado. A proporção que o rei se tornava medida na politica e na religião, a Coroa Portuguesa incorporava os símbolos tanto da Igreja quanto do Estado. A consequência dessa união foi uma íntima colaboração do poder estatal e eclesiástico (SORIANO, 2002, p. 37). No plano teórico, Peter Berger (1985, p. 42) explica que as instituições políticas e governamentais garantem sua legitimidade pelo fato da religião transformar o poder civil em poder sacramental.

Quanto à evangelização dos indivíduos em terras brasileiras, a Igreja Católica deteve o monopólio no controle da vida dos cidadãos, principalmente em matéria de educação e família. Assim, ditava o que era ou não moral e juridicamente aceitável, já que as leis vigentes no Brasil Colônia eram as mesmas de Portugal e, não raramente, confundiam-se com as leis de Deus, ou melhor, com as leis ditadas pela Igreja. Evidente, assim, que a atuação católica foi muito além do campo religioso, estendendo-se ao espaço social e político (EMMERICK, 2010, p. 145). A Igreja era também a única forma de serviço social que se conhecia, dando amparo aos velhos, órfãos e enfermos, cuidando da educação das crianças e organizando a maioria das festas populares (MOLINA, 2015, p. 37).

As relações entre Igreja Católica e Estado foram estreitas tanto no Brasil Colônia quanto no Império, pois, além de garantir a disciplina social, a Igreja também executava tarefas administrativas que hoje são atribuições do Estado, como o registro de nascimentos, de mortes e de casamentos. Em contrapartida, o Estado nomeava bispos e párocos, além de conceder licenças para construção de novas igrejas (CASTRO, 1998).

\section{Aspectos do Brasil imperial}


A Constituição editada em 1824 conferiu à Igreja Católica o título de religião oficial do Império, permitindo os mesmos controles e concedendo as prerrogativas da época colonial, demonstrando que a separação, nesse período, ainda era precária ou inexistente. A independência não modificou a tutela estatal sobre a Igreja e as mútuas influências. Ela continuou a atuar além do campo religioso, exercendo forte incidência no campo social e político (SILVA, 2010, p. 23).

A Constituição imperial de 1824 dispôs expressa autorização ao culto doméstico das demais religiões, realizado, sem propagação pública, somente no interior das residências dos seus fiéis ou em outros espaços físicos, proibidos os cultos públicos e as formas exteriores que denotassem templos (PONZILACQUA, 2016, p. 15).

Logo após a independência, os direitos civis reconhecidos sofreram restrições "em decorrência de uma herança colonial pautada na escravidão e no domínio do poder econômico da elite agroexportadora, o que contribuía para a negação dos direitos básicos à grande parte da população" (SILVA, 2010, p. 23).

A Constituição imperial trouxe no seu bojo uma série de dispositivos, regulando a legitimação da Igreja Católica, iniciando-se pelo preâmbulo, que inaugurava a ordem constitucional invocando a Santíssima Trindade. Isto indica que o poder imperial recorreu ao poder religioso católico para legitimação do poder e para coesão social (EMMERICK, 2010, p. 149).

Conforme Aguiar, Lima \& Santos (2013), durante o Brasil Império, o Estado e a Igreja mantiveram íntima e oficial ligação. Com o advento da República, esse laço se rompera, tornando o Estado, oficialmente, laico. Todavia, a Igreja manteve todos os privilégios decorrentes das relações anteriores. Em sua ótica, toda a trajetória brasileira, inclusive na atualidade, percebe-se a influência da religião desde a gênese, concepção e aplicação das normas sociais e jurídicas.

\section{Aspectos do Brasil republicano}

Na visão de Lísias Nogueira Negrão (2008, p. 263), a proclamação da República não significou a perda da hegemonia católica e de sua influência na vida cultural e politica brasileira. A Igreja continuou a cooperar eventualmente com o Estado republicano, como no combate às heresias messiânicas e a impor seus princípios religiosos às Constituições. A herança do catolicismo colonial e imperial foi, de certa forma, preservada, apesar das transformações republicanas. 
No período anterior à proclamação da República, por volta de 1890, houve um processo de crítica em desfavor da Igreja Católica, contribuindo para seu enfraquecimento e desprestígio. Os ideais revolucionários da época fomentavam o rompimento das algemas que ligavam o Estado à Igreja. Estes novos princípios eram observados no cenário político e no cenário religioso, sendo este último, amplamente combatido pelo ateísmo e pelo positivismo, com o devido apoio dos governantes (SCAMPINI, 1978, p. 82). Apaziguados os ânimos, os novos governantes cuidaram de efetivar a separação. Os primeiros rascunhos saíram das mãos do ministro da agricultura, Demétrio Ribeiro. Em razão das diversas retaliações sofridas, o General Deodoro da Fonseca pediu ao Ministro da Fazenda a criação de outro (SCAMPINI, 1978, p. 83). Após esse intenso debate, foi editado o Decreto n. 119A, de 7 de janeiro de 1890, rompendo os últimos laços da Igreja com o Estado, dando ao país o caráter laico, leigo ou não confessional (SCAMPINI, 1978, p. 84).

Com o início do regime republicano, houve efetiva separação entre Estado e Igreja. Todavia, o poder constituinte de 1891 ainda tinha arraigado algumas convicções religiosas, estando a Igreja, ainda que veladamente, exercendo influência corporativa sobre os parlamentares (SCAMPINI, 1978, p. 152).

A laicidade do Estado provocou no plano fático, lentas e gradativas modificações, vigendo até 1934, quando o presidente Getúlio Vargas convocou nova Assembleia Nacional Constituinte (REIMER, 2013, p. 57). A Constituição de 1934 manteve o Estado laico e mostrou maior abertura à colaboração das igrejas, embora condicionasse a liberdade de crença à ordem pública e aos bons costumes - o que poderia abrir brechas de interpretação da autoridade estatal em tais questões. Restringiu, indevidamente, a atuação de algumas denominações religiosas que fossem contrárias à ideologia da religião predominante, indicando a prevalência dos interesses católicos junto aos poderes constituídos do Estado (SCAMPINI, 1978, p. 150).

No capítulo referente aos direitos e garantias individuais, a Constituição de 1934 concede liberdade de religião:

Art. 113 - A Constituição assegura a brasileiros e a estrangeiros residentes no País a inviolabilidade dos direitos concernentes à liberdade, à subsistência, à segurança individual e à propriedade, nos termos seguintes: 1) Todos são iguais perante a lei. Não haverá privilégios, nem distinções, por motivo de nascimento, sexo, ra- 
ça, profissões próprias ou dos pais, classe social, riqueza, crenças religiosas ou ideias politicas (BRASIL,, 1934, [n.p.]).

Com a instauração do Estado Novo por Getúlio Vargas, foi decretada e outorgada a Constituição de 1937, que integrava elementos do autoritarismo vigente na Europa à época. Com relação à liberdade religiosa e ao Estado laico, não houve inovação em relação à anterior Constituição (OLIVEIRA, 2010, p. 69).

A Constituição de 1946, fruto da redemocratização do país, promulgada por uma Assembleia Constituinte, apresentou avanços na relação entre Estado e religião. O Estado laico foi reafirmado, a liberdade religiosa mantida, embora tenha condicionado a religião à ordem pública e aos bons costumes. A colaboração entre Igreja e Estado foi ampliada, com vedação dos entes federados a lançarem impostos sobre templos de qualquer culto (SCAMPINI, 1978, p. 152).

A Constituição de 1946 trouxe algumas inovações: tratou de restaurar o princípio constitucional liberal moderno da separação e interdependência dos três poderes (Art. 7, inciso VII, alínea b); assinalou o retorno dos direitos fundamentais e das garantias que haviam sido suprimidos na Constituição de 1937; restaurou a liberdade na manifestação de pensamento sem censura; a inviolabilidade do sigilo de correspondência (Art. 141, parágrafo $6^{\circ}$ ) estava garantida, assim como a inviolabilidade da casa como asilo do indivíduo (Art. 141, Parágrafo 15) (Reimer, 2013, p. 64).

A Constituição de 1967, ao tratar dos direitos e garantias individuais, assegurou a liberdade religiosa aos brasileiros:

Art. 150 - A Constituição assegura aos brasileiros e aos estrangeiros residentes no País a inviolabilidade dos direitos concernentes à vida, à liberdade, à segurança e à propriedade, nos termos seguintes: $\S 1^{\circ}$ - Todos são iguais perante a lei, sem distinção, de sexo, raça, trabalho, credo religioso e convicções políticas (BRASIL, 1937, [n.p.]).

Durante a vigência da Constituição de 1967, a mesma sofreu a Emenda Constitucional n. 1, de 17 de outubro de 1969. Esta nova Constituição também trouxe diversos dispositivos acerca da liberdade religiosa. O primeiro a ser mencionado trata da separação entre Estado e Igreja, conforme artigo $9^{\circ}$, que estabelecia que à União, aos Estados, ao Distrito Federal e aos Municípios é vedado estabelecer cultos religiosos ou igrejas, subvencioná-los, embaraçar-lhes o exercício ou manter com eles, ou seus representantes, relações de dependência ou aliança, ressalvada a colaboração de interesse público, na forma e nos limites da 
lei federal, notadamente no setor educacional, no assistencial e no hospitalar (REIMER, 2013, p. 69).

A história brasileira apresenta fatos e incidentes notórios que demonstram que não houve liberdade de consciência durante o período militar, mesmo com a garantia constitucional, a exemplo da censura aos meios de comunicação. Semelhante ocorreu no âmbito da liberdade de religião, pois, caso alguma religião ou líder esboçasse no culto, ou na crença, algum ideal de justiça social, apareceria como suspeito de inclinação comunista, estando sujeito a detenções arbitrárias e fora da legalidade (OLIVEIRA, 2010, p. 28).

Segundo Reimer (2013, p. 73), a década de 1980 marcou a inicialização do processo de redemocratização do país, concretizando-se com a promulgação da Constituição de 1988, tendo esta Carta Magna reconhecido muitos direitos, dentre eles, a liberdade religiosa em suas mais variadas nuances. Quanto à liberdade de consciência, de crença e de culto, foram considerados direitos invioláveis. Todavia, a inviolabilidade prescrita, não tem caráter absoluto. Não existem direitos absolutos, pois, todos encontram limites nos demais direitos, também consagrados na Carta Magna. A liberdade à consciência é mais ampla que a de crença, pois, envolve questões religiosas, politicas e filosóficas. Já a liberdade de crença está relacionada apenas com aspectos religiosos.

O artigo $5^{\circ}$, no inciso VIII da Constituição Federal de 1988, assegura que:

ninguém será privado de direitos por motivo de crença religiosa ou de convicção filosófica ou política, salvo se as invocar para eximirse de obrigação legal a todos imposta e recusar-se a cumprir prestação alternativa, fixada em lei (BRASIL, 1988, [n.p.]).

Conforme Soriano (2002, p. 10), o direito à liberdade religiosa é múltiplo, e compreende diversos direitos. Deve ser considerado um direito composto, tendo, ainda, possibilidade de decomposição em quatro vertentes: 1) liberdade de consciência: de foro individual e mais ampla que a liberdade de crença; 2) liberdade de crença: conhecida como liberdade de religião ou liberdade religiosa; 3) liberdade de culto: resulta da exterioridade da crença; e 4) liberdade de organização religiosa: decorre do Estado laico.

Na visão de Silva (2007, p. 250), as relações entre religião e Estado sofrem classificações conforme o grau de intensidade. Ao analisar essa relação, indicou três sistemas sujeitos a gradações: a confusão, a união e a separação. Para Rive- 
ro \& Moutouh (2006, p. 526), o sistema de separação, decorre do conceito de Estado Laico, que "é, pois, aquele que se situa fora de toda obediência religiosa e deixa no setor privado as atividades confessionais". O Estado hesitou em privar sua autoridade de um alicerce sobrenatural e em deixar autonomia às igrejas. No sistema laico, a independência recíproca das duas áreas é completa, sendo que um não penetra no outro. Mas, são possíveis diversas modalidades de laicidade, já que a separação pode deixar espaço para relações, com maior ou menor cordialidade, ou, ainda, assumindo a forma de uma ignorância total do fato religioso pelo Estado.

Para Santos Júnior (2007, p. 63), a laicidade determinada pela Constituição Federal de 1988 é a base ideológica do regime da liberdade de religião e do direito fundamental daí decorrente, estando disposta no inciso I, do artigo 19, da Carta Constitucional. Na sua visão, há dois modelos básicos de laicismo estatal. O primeiro modelo de Estado laico é aquele que pugna por uma separação tendente a restringir a religião ao foro íntimo das pessoas, isolando-a do espaço público. O segundo modelo é aquele que, enxergando no fenômeno religioso um importante elemento de integração social, permite expressões de religiosidade nos espaços públicos, chancelando-as de diversos modos. Logo, o laicismo expressa o sistema jurídico-político no qual, Estado e organizações religiosas não sofrem interferências recíprocas ao atendimento de suas finalidades institucionais.

A laicidade, por seu turno, seria simplesmente a qualidade de laico, o caráter de neutralidade religiosa do Estado. Entre um modelo e outro, há diversas gradações, considerando as peculiaridades de cada ordenamento jurídico nacional e a tradição de cada povo, havendo, também, circunstâncias históricas específicas que explicam o porquê da prevalência em um dado sistema jurídico de uma concepção mais próxima deste ou daquele modelo. O Brasil mantém os princípios da separação e da colaboração.

Giumbelli (2002, p. 454), afirma que a laicidade é uma categoria que tende a remeter para modelos. Esses modelos não devem ser confundidos com as descrições da realidade, ou seja, não devem ser sinônimo do funcionamento efetivo das sociedades seculares. A redefinição das fronteiras entre o religioso e o político é um desafio à ideia de secularização na contemporaneidade. Tal fato indica que nenhum modelo ideal dará conta das complexas interações entre religião e Estado. 
Segundo Habermas (2007), no Estado regido por uma Constituição democrática, onde o poder político não mais se fundamenta no transcendental, faz-se necessário preencher a lacuna em termos cosmológicos do referido poder:

As expectativas e os modos de pensar e de se comportar dos cidadãos, que não podem ser simplesmente impostos mediante o direito, podem ser, no entanto, explicitados a partir desses dois componentes da legitimação. As condições para uma participação bem-sucedida na prática comum de autodeterminação definem o papel de cidadão do Estado: os cidadãos devem respeitar-se reciprocamente como membros de sua respectiva comunidade política, dotados de iguais direitos, apesar de seu dissenso em questões envolvendo convicções religiosas e visões de mundo (HABERMAS, 2007, p. 157).

A liberdade de religião é inerente à condição humana, e a religiosidade é um fenômeno sociológico que ganha importância jurídica, graças aos princípios constitucionais de liberdade. Todavia, a secularização em países de tradição católica não se dá na mesma velocidade que em países de tradição calvinista, por exemplo. Conquanto constitua um fenômeno que alcança todo o mundo ocidental, apresenta-se diferente nos diversos Estados, por razões diversas, dentre as quais se inclui até mesmo a concepção teológica sustentada pela religião majoritária (OLIVEIRA, 2011).

\section{Conclusão}

Pode-se observar na história do Brasil, que o vínculo entre religião e Estado não se rompeu. Percebem-se algumas rupturas entre uma Constituição e outra, gerando dificuldades para se estabelecer os limites de atuação entre religião e Estado, em que pese a adoção do sistema de separação entre Estado e Igreja. Uma coisa é a letra da lei, outra, a forma como os agentes se articulam e influenciam a vida social. No caso brasileiro, a força da religião majoritária, o catolicismo, com tantos privilégios e prerrogativas ao longo de séculos, sedimentou-se na sociedade, especialmente no período colonial, na forma de cultura e de visão de mundo, modelando a ação social. Essa influência cultural e religiosa criou o que se pode chamar de tradição, sendo reproduzida nas Constituições brasileiras.

O período colonial foi marcado pela união da Igreja Católica com o Estado, onde a primeira atuou em assuntos diversos além da esfera eclesiástica, enquanto agia sob o patrocínio do Estado. A Constituição imperial de 1824 manteve 
o catolicismo como religião oficial, limitando as demais confissões e religiões. As relações entre Estado e Igreja, apesar de as disposições constitucionais separatistas da Constituição de 1891 serem destoantes do plano dos fatos, muito contribuiu para a garantia da liberdade e da igualdade dos cidadãos. A Constituição republicana de 1891 foi um marco para a laicidade do Estado brasileiro. As Constituições subsequentes, sob a égide do regime jurídico constitucional separatista entre religião e Estado, não foi suficiente, nem no plano jurídico, nem no plano social, para configurar uma ampla distanciação legal.

A Constituição de 1988 consagrou a liberdade religiosa no Brasil como um direito fundamental e como resposta ao tempo histórico de reabertura, após um período de regime ditatorial militar, que exigiu um novo pacto constitucional. Ao mesmo tempo, a Carta Magna vigente delimitou a relação entre Estado e as organizações religiosas, através da noção de Estado laico e das respectivas vedações que a laicidade impõe. As organizações religiosas têm o direito de autoorganização e autodeterminação, cabendo ao Estado protegê-las, sem distinguir entre elas, sem beneficiar uma delas.

O modelo teórico da separação entre religião e Estado, possivelmente não é o ponto de partida mais apropriado para analisar a realidade brasileira. O regime de separação entre ambas as instituições sociais, assinalado pelas Constituições nacionais, não se dá uniformemente, mas com movimentos assimétricos, avanços e retrocessos, com maior ou menor proximidade entre um e outro. Ademais, determinar a exata relação entre a religião e o poder estatal, ante o entremeio do sagrado e a compreensão da religião como um fato social, com influxo na maneira de agir dos indivíduos ou de uma coletividade, não é tarefa fácil. As fronteiras não são claras e a influência da religião permanece, apesar do regramento jurídico, indicando que o campo de atuação da religião é profundo, enraizando-se como cultura e como cosmovisão.

\section{Referências bibliográficas}

AGUIAR, Itamar Pereira de; LIMA, Bruna Havena Aragão; SANTOS, Guilherme Ribeiro Miranda dos. Religião e sociedade: as relações entre o estado e as concepções religiosas na formação do ordenamento social e jurídico. Cadernos de Ciências Sociais Aplicadas. Vitória da Conquista, ano XIII, n. 12, 2013. p. 9-31.

ÁGUILA, Rafael del. Manual de ciencia politica. Madrid: Trotta, 2005. 
ASSIS, Olney Queiroz; KUMPEL, Vitor Frederico. Manual de antropologia juridica. São Paulo: Saraiva, 2011.

AZAMBUJA, Darcy. Teoria geral do Estado. 36 ed. São Paulo: Globo, 1997.

BERGER, Peter. O dossel sagrado: elementos para uma teoria sociológica da religião.São Paulo: Paulinas, 1985.

BRASIL. Constituição (1934). Constituição da República Federativa do Brasil. Brasília: Senado Federal. Disponivel em http://www.planalto.gov.br/ccivil_03/constituicao/constituicao34.htm. Acesso em 25 de fevereiro de 2021.

BRASIL. Constituição (1937). Constituição da República Federativa do Brasil. Brasília: Senado Federal. Disponivel em http://www.planalto.gov.br/ccivil_03/Constituicao/Constituicao37.htm. Acesso em25 de fevereiro de 2021.

BRASIL. Constituição(1988). Constituição da República Federativa do Brasil. Brasília: Senado Federal. Disponivel em https://www2.senado.leg.br/bdsf/bitstream/handle/id/518231/CF88_Livro_EC 91_2016.pdf>. Acesso em25 de fevereiro de 2021.

CASTRO, José Luiz. A organização da Igreja Católica na Capitania de Goiás (1726-1824). Dissertação (Mestrado em História). Goiânia: UFG, 1998.

COUTINHO, José Pereira. Religião e outros conceitos. Sociologia, v. XXIV. Porto, 2012, p. 171-193. $\quad$ Disponivel em https://ler.letras.up.pt/uploads/ficheiros/10763.pdf. Acesso em 25 de fevereiro de 2021.

DALLARI, Dalmo de Abreu. Elementos de teoria geral do Estado. São Paulo: Saraiva, 2006.

DALLARI, Dalmo de Abreu. O futuro do Estado. $2^{\circ}$ ed. São Paulo: Saraiva, 2007.

DANTAS, Ivo. Teoria do Estado contemporâneo. Rio de Janeiro: Forense, 2008.

DURKHEIM, Émile. As formas elementares da vida religiosa. São Paulo: Martins Fontes, 1996.

ELIADE, Mircea. O sagrado e o profano. São Paulo: Martins Fontes, 1992.

EMMERICK, Rullian. As relações Igreja/Estado no direito constitucional brasileiro: um esboço para pensar o lugar das religiões no espaço público na contemporaneidade. Revista Latino-Americana.Rio de Janeiro,n. 5, 2010. p. 144-172.

GIUMBELLI, Emerson. O fim da religião: dilemas da liberdade religiosa no Brasil e na França. São Paulo: Attar, 2002.

HABERMAS, Jürgen. Entre naturalismo e religião: estudos filosóficos. Rio de Janeiro: Tempo Brasileiro, 2007.

HOBBES, Thomas. Leviatã ou matéria, forma e poder de um Estado eclesiástico e civil. São Paulo: Martin Claret, 2003.

KELSEN, Hans. Teoria geral do direito e do Estado. $3^{\circ}$ ed. São Paulo: Martins Fontes, 2000. 
LOCKE, John. Segundo tratado do governo civil. Petrópolis: Vozes, 2018.

MAQUIAVEL, Nicolau. O príncipe. São Paulo: Penguin, 2010.

MALUF, Sahid. Teoria geral do Estado. São Paulo: Saraiva, 1998.

MARTINS, Edson; CÂMARA, Uipirangi Franklin da Silva. Direito e religião no Brasil. Anima.Curitiba, ano X, n. 17, 2017. Disponivel emhttp://animaopet.com.br/pdf/anima17/INTERNO/2-interno-Direito-e-religiao-no-Brasil-

Martins-Cama-ra.pdf. Acesso em25 de fevereiro de 2021.

MOLINA, Matias M.História dos jornais no Brasil. São Paulo: Schwarcz, 2015.

NEGRÃO, Lísias Nogueira. Pluralismo e multiplicidades religiosas no Brasil contemporâneo. Sociedade e Estado. Brasília, v. 23, n. 2, 2008. p. 261-279.

OLIVEIRA, Patrícia Elias Cozzolino. A proteção constitucional e internacional do direito à liberdade de religião. São Paulo: Verbatim, 2010.

OLIVEIRA, Fábio Dantas. Aspectos da liberdade religiosa no ordenamento jurídico brasileiro. 2011. Disponivel emhttps://jus.com.br/artigos/19770/aspectos-daliberdade-religiosa-no-ordenamento-juridico-brasileiro. Acesso em25 de fevereiro de 2021.

PONZILACQUA, Marcio Henrique Pereira. Direito e religião: abordagens específicas. Ribeirão Preto: SDDS/FDRP USP, 2016.

REALE, Miguel. Globalização e Estado nacional, filosofia e teoria politica: ensaios. São Paulo: Saraiva, 2000.

REIMER, Haroldo. Liberdade religiosa na história e nas Constituição do Brasil. São Leopoldo: Oikos, 2013.

RIVERO, Jean; MOUTOUH, Hugues. Liberdades públicas. São Paulo: Martins Fontes, 2006.

ROUSSEAU, Jean-Jacques. O contrato social. $3^{\circ}$ ed. São Paulo: Martins Fontes, 1999.

SANTOS JUNIOR, Aloísio Cristovam dos. A liberdade de organização religiosa e o Estado laico brasileiro. São Paulo: Mackenzie, 2007.

SCAMPINI, José. A Liberdade religiosa nas Constituições brasileiras: estudo filosófico-jurídico comparado. Petrópolis: Vozes, 1978.

SCOTT, John. Sociologia: conceitos-chave. Rio de Janeiro: Zahar, 2006.

SENA, José Roberto. A religião nas concepções dos clássicos Marx e Durkheim: felicidade ilusória ou transfiguração da sociedade?Diversidade Religiosa. João Pessoa: v. 6, n. 1, 2016. p. 64-86.

SILVA, Eliane Moura. Religião, diversidade e valores culturais: conceitos teóricos e a educação para a cidadania. Rever. São Paulo: PUC-SP, n. 2, ano IV, 2004. p. $1-14$.

SILVA, José Afonso. Curso de direito constitucional positivo. $28^{\circ}$ ed. São Paulo: Malheiros, 2007. 
SILVA, Alda Fernanda Sodré Bayma. A constitucionalização da liberdade religiosa enquanto direito fundamental: uma análise da tutela e efetividade do direito à liberdade religiosa à luz da Constituição Federal de 1988 e jurisprudências. Monografia (Graduação em Direito). São Luís: UFMA, 2010.

SOARES, Mario Lúcio Quintão. Teoria do Estado: novos paradigmas em face da globalização. $3^{\circ}$ ed. São Paulo: Atlas, 2008.

SORIANO, Aldir Guedes. Liberdade religiosa no direito constitucional e internacional. São Paulo: Juarez de Oliveira, 2002.

Recebido em 26/02/2021

Aceito para publicação em 26/03/2021 